\title{
Studies on Genetic Variability, Heritability and Genetic Advance in Elite Genotypes of Sugarcane (Saccharum officinarum L.)
}

\author{
N.R. Koli ${ }^{1}$, Manoj Kumar ${ }^{1}$, Sandhya ${ }^{1}$, R.K. Meena ${ }^{2}$, \\ D.S. Meena ${ }^{2}$ and Harphool Meena ${ }^{2}$ \\ ${ }^{1}$ Department of Genetics \& Plant Breeding, Agricultural Research Station, Ummedganj Farm \\ Kota - 324001, (Agricultural University, Kota), India \\ ${ }^{2}$ Department of Agronomy, Agricultural Research Station, Ummedganj Farm Kota - 324001, \\ (Agricultural University, Kota), India \\ *Corresponding author
}

\begin{tabular}{|l|}
\hline K e y w o r d s \\
$\begin{array}{l}\text { Genetic variability, } \\
\text { Heritability, Genetic } \\
\text { advance as \% of mean, } \\
\text { Range, Cane yield and } \\
\text { quality characters in elite } \\
\text { genotypes of sugarcane } \\
\text { (Saccharum officinarum } \\
\text { L.) }\end{array}$ \\
\hline Article Info \\
\hline $\begin{array}{l}\text { Accepted: } \\
\text { 10 July } 2019 \\
\text { Available Online: } \\
\text { 10 August } 2019\end{array}$ \\
\hline
\end{tabular}

A B S T R A C T
An experiment was conducted during kharif 2017-18 to generate information on yield and yield contributing traits in elite genotypes of sugarcane (Saccharum officinarum L.). The present investigation was undertaken to study the genetic variability for cane yield (t/ha), commercial cane sugar (t/ha), sucrose \% in juice, brix \% in juice, CCS \% in juice, number of millable canes $(0,000 / \mathrm{ha})$, stalk length $(\mathrm{m})$, stalk diameter $(\mathrm{cm})$ and single cane weight (Kg) at harvesting stage. The significant differences were observed for all the traits studied. Among the seventeen elite genotypes of sugarcane revealed, presence of sufficient variability among these traits, which was confirmed by broad range of variability. The phenotypic coefficient of variation (PCV) exhibited higher values than genotypic coefficient of variation (GCV) for all the traits, indicating the environmental effect. High estimates of genotypic coefficient of variation (GCV) for commercial cane sugar (8.19 t/ha), single cane weight $(7.25 \mathrm{Kg})$ and CCS \% in juice (6.72) indicated the preponderance of additive gene. High heritability in broad sense was recorded for sucrose $\%$ in juice (92.56), CCS \% in juice (90.31) single cane weight (80.55), brix \% in juice (75.18) and stalk length (70.07). High heritability accompanied with low genetic advance for sucrose $\%$ in juice, CCS \% in juice, stalk length and single cane weight at harvesting (12 months after sowing), indicating the non-additive gene action and this could be improved through hybridization.

\section{Introduction}

Genetic variability is the pre requisites of any successful breeding programme. The conventional breeding programme is very limited to the gene pool of the species and it is difficult to trace out the presence or absence of specific genes. Development of high yielding genotypes requires a thorough knowledge of genetic variability in yield and its contributing traits. The observed variability is a combined estimate of genetic and environmental causes, whereas, genetic variability alone is heritable. Moreover, estimates of genetic variability across different environments helps to exploit complete genetic variability to exercise 
selection for development of yield contributing traits. Estimate of heritability alone does not give an idea of expected genetic gain in the next generation but also be considered in the conjunction with genetic advance. Direct selection for yield per se is not effective, because yield is a complex character which is associated with several other component characters. The large spectrum of genetic variability in segregating population depends on the amount of the genetic variability present in the genotypes and offer better scope for selection. The magnitude of heritable variation in the traits studied has immense value in understanding the potential of the genotype for further breeding programme. Assessment of genetic variability for yield and its contributing traits becomes absolutely essential before planning for an appropriate breeding strategy for genetic improvement. Genetic variability parameters such as genetic and phenotypic coefficient of variation are useful tools in detecting the amount of variability present in the germplasm.

High heritability coupled with high genetic advance would be more useful tool in predicting the resultant effect in selection of the best genotypes for yield and its attributing traits. It helps in detecting the influence of environment on the expression the genotypic and phenotypic reliability of traits. In view of the above facts, the present investigation was undertaken to study the magnitude of genetic variability among the tested genotypes of sugarcane.

\section{Materials and Methods}

The experimental material for the present investigation was carried out at the Agricultural Research Station, Ummedganj farm, Kota (Raj.), during kharif 2017- 2018. The experiment was laid out in a randomized complete block design with three replications along with row spacing of $90 \mathrm{~cm}$. The recommended packages of practices were followed to raise the healthy crop. The observations were recorded on ten equally competitive plants were randomly selected for cane yield (t/ha), CCS yield (t/ha), CCS \% in juice, sucrose $\%$ in juice, brix $\%$ in juice, number of millable cane $(0,000 / \mathrm{ha})$ stalk length, stalk diameter (m.) and single cane weight $(\mathrm{kg})$. The pooled data over the years were statistically analyzed as per the standard procedure for variability (Panse and Sukhatme 1984) and coefficient of variations as per suggested by Burton and Devane (1953). Heritability in broad sense and expected genetic advance as percent of mean were estimated as per suggested by Johnson et.al. (1955).

\section{Results and Discussion}

The analysis of variance showed significant differences for all the traits studied. Table 1 indicated significantly higher mean value for cane yield $(85.16,84.45 \mathrm{t} / \mathrm{ha})$, commercial cane yield (11.07, $10.07 \mathrm{t} / \mathrm{ha}), \mathrm{CCS} \%$ in juice (13.01, 11.93), sucrose \% in juice (18.51, $17.40)$ and brix $\%$ in juice $(20.28,20.24)$ in elite genotype of sugarcane $\mathrm{CoPb} 14212$ followed by $\mathrm{CoPb} 14185$ respectively. The extent of variability with respect to various characters for different elite genotypes of sugarcane measured in terms of range, mean, genotypic and phenotypic coefficient of variation along with heritability $\left(\mathrm{h}^{2}\right)$ in broad sense and expected genetic advance as per cent of mean presented in Table 2. The range of variation was high for cane yield t/ha (70.46 - 85.16) and number of millable cane per $0,000 /$ ha $(71.33$ - 82.94), however, the remaining characters, viz. CCS t/ha (7.68 $11.07)$, CCS \% in juice $(10.02-13.01)$, sucrose $\%$ in juice (14.90 -18.51), brix \% in juice (17.25-21.27), stalk length (1.9 -2.44 m) and stalk diameter $(1.93-2.42 \mathrm{~cm})$ exhibited medium to low range of variability. 
Table.1 Mean and Range performance for 9 attributes in elite genotypes of sugarcane at harvesting stage (12 month after sowing)

\begin{tabular}{|c|c|c|c|c|c|c|c|c|c|}
\hline $\begin{array}{l}\text { Genotypes/ } \\
\text { Attributes }\end{array}$ & $\begin{array}{l}\text { Cane } \\
\text { yield } \\
\text { (t/ha) }\end{array}$ & $\begin{array}{c}\text { CCS } \\
\text { (t/ha) }\end{array}$ & $\begin{array}{l}\text { CCS } \\
\% \text { in } \\
\text { juice }\end{array}$ & $\begin{array}{c}\text { Sucrose } \\
\% \text { in } \\
\text { juice }\end{array}$ & $\begin{array}{l}\text { Brix \% } \\
\text { in juice }\end{array}$ & $\begin{array}{c}\text { No. of } \\
\text { NMC } \\
(0,000 / h a)\end{array}$ & $\begin{array}{l}\text { Stalk } \\
\text { lengt } \\
\text { h }(\mathbf{m})\end{array}$ & $\begin{array}{c}\text { Stalk } \\
\text { Diamete } \\
\text { r (cm) }\end{array}$ & $\begin{array}{c}\text { Single } \\
\text { cane wt. } \\
\text { (kg) }\end{array}$ \\
\hline Co 14035 & 82.70 & 8.77 & 10.59 & 15.74 & 18.81 & $82.55^{*}$ & 1.91 & 2.14 & 0.99 \\
\hline СoH 14261 & 75.41 & 8.87 & 11.77 & 17.18 & 19.82 & $79.10 *$ & 2.13 & 2.03 & 0.86 \\
\hline CoH 14262 & 79.48 & 9.34 & 11.75 & 17.58 & $21.27 *$ & 77.72 & 2.16 & 2.03 & 0.94 \\
\hline CoLk 14203 & 80.01 & 8.90 & 11.13 & 16.56 & 19.86 & $81.99 *$ & 2.16 & 2.21 & $1.06 *$ \\
\hline CoLk 14204 & 81.67 & $9.70 *$ & 11.89 & 17.42 & $20.27^{*}$ & $82.94 *$ & 2.17 & 2.31 & $1.05^{*}$ \\
\hline CoLk 14205 & 71.82 & 8.51 & 11.86 & 17.12 & 19.31 & 77.22 & 2.14 & 2.05 & 0.96 \\
\hline CoPb 14183 & 70.46 & 8.48 & $12.03 *$ & 17.51 & $20.08 *$ & 76.89 & 2.19 & 2.24 & $1.03 *$ \\
\hline CoPb 14184 & 76.65 & 7.68 & 10.02 & 14.90 & 17.85 & 75.03 & 2.26 & 2.12 & 0.96 \\
\hline CoPb 14185 & $84.45^{*}$ & $10.07 *$ & $11.93^{*}$ & $17.40 *$ & $20.05^{*}$ & $80.28 *$ & 2.20 & 1.95 & 0.87 \\
\hline CoPb 14212 & $85.16^{*}$ & $11.07^{*}$ & $13.01 *$ & $18.51 *$ & $20.24 *$ & 75.41 & 2.21 & 1.93 & 0.90 \\
\hline CoPb 14231 & $82.22 *$ & $10.03^{*}$ & $12.61 *$ & $18.13^{*}$ & $20.28 *$ & 73.75 & 2.30 & 2.06 & 0.93 \\
\hline CoS 14232 & 82.40 & 9.66 & 11.72 & 16.91 & 19.05 & 71.33 & 2.44 & 2.11 & 0.95 \\
\hline CoS 14233 & 81.09 & 8.40 & 10.36 & 15.43 & 18.52 & 75.80 & 2.22 & 2.14 & 0.90 \\
\hline $\operatorname{CoS} 767$ & 80.53 & 8.59 & 10.66 & 15.74 & 18.58 & 78.50 & 2.17 & 2.42 & 0.88 \\
\hline $\operatorname{CoS} 8436$ & 77.82 & 8.63 & 11.11 & 16.45 & 19.54 & 79.54 & 2.23 & 2.22 & 0.84 \\
\hline Co Pant 97222 & 82.40 & 9.36 & 11.36 & 16.40 & 18.48 & 78.01 & 2.38 & 2.24 & 0.81 \\
\hline Co 05011 & 79.60 & 9.46 & 11.89 & 17.03 & 18.89 & 80.62 & 2.40 & 2.17 & 0.92 \\
\hline Mean & 79.64 & 9.15 & 11.51 & 16.82 & 19.46 & 78.04 & 2.22 & 2.14 & 0.93 \\
\hline Range & $\begin{array}{l}70.46- \\
85.16\end{array}$ & $\begin{array}{l}7.68- \\
11.07\end{array}$ & $\begin{array}{c}10.02- \\
13.01\end{array}$ & $\begin{array}{c}14.90- \\
18.51\end{array}$ & $\begin{array}{c}17.25- \\
21.27\end{array}$ & $\begin{array}{c}71.33- \\
82.94\end{array}$ & $\begin{array}{l}1.91- \\
2.44\end{array}$ & $\begin{array}{l}1.93- \\
2.42\end{array}$ & $\begin{array}{c}0.81- \\
1.06\end{array}$ \\
\hline SE $( \pm)$ & 2.79 & 0.30 & 0.14 & 0.15 & 0.27 & 1.65 & 0.04 & 0.05 & 0.02 \\
\hline
\end{tabular}

Table.2 Genetic variability parameters various attributed of elite sugarcane genotypes at harvesting stage (12 months after sowing)

\begin{tabular}{|l|c|c|c|c|c|c|c|}
\hline Characters & Mean & Range & GCV & PCV & $\begin{array}{c}\text { Heritability } \\
\text { (bs) }\end{array}$ & $\begin{array}{c}\text { Genetic } \\
\text { advance }\end{array}$ & $\begin{array}{c}\text { Genetic } \\
\text { Advance as } \\
\text { \% } \\
\text { mean }\end{array}$ \\
\hline Cane yield (t/ha) & 79.64 & $70.46-85.16$ & 3.74 & 7.14 & 27.44 & 2.15 & 4.21 \\
\hline CCS (t/ha) & 9.15 & $7.68-11.07$ & 8.19 & 10.05 & 66.39 & 1.31 & 1.61 \\
\hline CCS\% in juice & 11.51 & $11.02-13.01$ & 6.72 & 7.07 & 90.31 & 1.84 & 1.94 \\
\hline Sucrose \% in juice & 16.82 & $14.90-18.51$ & 5.66 & 5.89 & 92.56 & 2.33 & 2.42 \\
\hline Brix \% in juice & 19.46 & $17.25-21.27$ & 4.28 & 4.94 & 75.18 & 1.65 & 1.91 \\
\hline No. of NMC (0,000/ha) & 78.04 & $71.33-82.94$ & 3.47 & 5.05 & 47.23 & 3.38 & 4.92 \\
\hline Stalk length (m) & 2.22 & $1.91-2.44$ & 5.15 & 6.16 & 70.07 & 0.211 & 0.25 \\
\hline Stalk Diameter (cm) & 2.14 & $1.93-2.42$ & 5.22 & 7.09 & 54.25 & 0.16 & 0.21 \\
\hline Single cane weight (kg) & 0.93 & $0.81-1.06$ & 7.25 & 8.08 & 80.55 & 0.14 & 0.16 \\
\hline
\end{tabular}


This variation shows greater genetic variability among the elite genotypes of sugarcane and responsiveness of the attributes for further improvement. In overall, the phenotypic coefficient of variation were higher than the genotypic one s for all the traits, indicating the effect of environment on the manifestation of these traits and narrow difference between genotypic coefficients of variation and phenotypic coefficient of variation values indicated, minimum environment influence and this was supported by higher values of heritability for different characters. High phenotypic and genotypic coefficients of variation were found for commercial cane sugar $(7.07 \& 6.72 \mathrm{t} / \mathrm{ha}$. $)$ and single cane yield $(8.08$ \& $7.25 \mathrm{~kg}$.) whereas for remaining traits these values were found moderate to low. Similar results were reported by Kadian et al., (1997), Gupta \& Chatterjee (2002), Tyagi et al., (1998) and Kumar \& Ram (2014) in sugarcane.

The estimates of heritability act as a predictive instrument in exercising the reliability of phenotypic value. Therefore, it helps the breeder to make selection for a particular character when heritability is high. The genetic advance is a useful indicator of the progress that can be expected as a result of exercising selection on the pertinent population. High heritability in broad sense indicates lesser influence of environment in the gene expression. Sucrose \% in juice, commercial cane sugar, and single cane weight, brix $\%$ in juice and stalk length showed high estimates of heritability. On the other hands remaining traits indicated moderate to low degree of heritability. These results are in conformity Gupta and Chatterjee (2002) and Kumar \& Ram (2014) in sugarcane High estimates of genetic advance were observed for sucrose $\%$ in juice only and other attributes indicated low genetic gain. In the present study, high heritability accompanied with low genetic advance was found for single cane weight and CCS \% in juice, these traits are more likely under the control of non-additive gene action and selection for these traits would be less effective. Rest of the traits had low to moderate heritability with low genetic advance, indicating the influence of environment on these traits. These findings are in agreement with Gupta and Chatterjee (2002) and Kumar \& Ram (2014).

\section{Acknowledgement}

The authors are greatly acknowledge the Director, ICAR-IISR, Lucknow, Director \& Zonal Director Research, Agriculture University, Kota for providing financial assistance to conduct this experiments.

\section{References}

Burton G S and Devane E J. 1953. Estimating heritability in tall fescue (Festuca arundinaceae) from replicated clonal material. Agron. J., 45: 478-481.

Gupta R.K and Chatterjee A. 2002. Study on some genetic parameters and its implication in selection of sugarcane. Cooperative sugar 33 (10): 823-25.

Johnson H W, Robinson H F and Comstock R E. 1955. Estimates of genetic and environmental variability in soya bean. Agron. J., 47: 314-318.

Kadian S P, Chander Kishore C and Sabharawal P.S. 1997. Genetic variability and heritability in sugarcane. Indian Sugar XL. VI (12): 893-95.

Kumar A and Ram B. (2014). Variability, heritability and genetic advance among the somaclones of sugarcane (Saccharum spp. Complex). Indian journal of sugarcane technology. 29 (02): 55-58.

Panse V G and Sukhatme P V. 1984. Statistical methods for Agricultural Workers. ICAR, New Delhi.

Tyagi S D and Singh D.N.1998. Studies on genetic variability in stalk character in sugarcane. Indian sugar, XL VIII(4): 25962. 


\section{How to cite this article:}

Koli, N.R., Manoj Kumar, Sandhya, R.K. Meena, D.S. Meena and Harphool Meena. 2019. Studies on Genetic Variability, Heritability and Genetic Advance in Elite Genotypes of Sugarcane (Saccharum officinarum L.). Int.J.Curr.Microbiol.App.Sci. 8(08): 1255-1259. doi: https://doi.org/10.20546/ijcmas.2019.808.147 